\title{
Effect of Photoinitiator Type and Photoactivation Condition on the Physical-Mechanical Properties of Orthodontic Resins
}

Efeito do Tipo de Fotoiniciador e da Condição de Fotoativação nas Propriedades Físico-Mecânicas das Resinas Ortodônticas Efecto del Tipo de Fotoiniciador y Condición de Fotoactivación sobre las Propiedades Físico-Mecánicas de las Resinas de Ortodoncia

Priscila Maito ROSEIRA

MSc, School of Health Sciences, Graduate Program in Dentistry, Universidade Positivo, Curitiba - PR, Brazil

Camila de Siqueira GOMES

MSc, School of Health Sciences, Graduate Program in Dentistry, Universidade Positivo, Curitiba - PR, Brazil Francielle TOPOLSKI

PhD, Professor, School of Health Sciences, Graduate Program in Dentistry, Universidade Positivo, Curitiba - PR, Brazil https://orcid.org/0000-0003-4557-553X

Carla Castiglia GONZAGA

PhD, Professor, School of Health Sciences, Graduate Program in Dentistry, Universidade Positivo, Curitiba - PR, Brazil https://orcid.org/0000-0001-6374-1605

Alexandre MORO

PhD, Professor, School of Health Sciences, Graduate Program in Dentistry, Universidade Positivo, Curitiba, PR, Brazil. Associate Professor, Department of Orthodontics, Universidade Federal do Paraná, Curitiba - PR, Brazil https://orcid.org/0000-0002-3127-1837

Roberta Caroline Bruschi ALONSO PhD, Professor, Department of Restorative Dentistry, Universidade Metropolitana de Santos, Santos -SP, Brazil https://orcid.org/0000-0001-7128-8687 Gisele Maria Correr NOLASCO PhD, Professor, School of Health Sciences, Graduate Program in Dentistry, Universidade Positivo, Curitiba - PR, Brazil. Adjunct Professor, Department of Restorative Dentistry, Universidade Federal do Paraná, Curitiba - PR Brazil https://orcid.org/0000-0002-5032-0948

\section{Abstract}

Purpose: The aim of this study was to evaluate the physical-mechanical properties of experimental orthodontic resins, containing different photoinitiators systems and photoactivated through a ceramic bracket, using a high irradiance and wide spectrum light emitting diode curing unit. Methods: Experimental resin composites (50:50 BisGMA/TEGDMA: 60\% feldspar silanized particles) were formulated with different photoinitiators according to the following groups: phenylpropaneamine + amine DMAEMA (PPD), camphorquinone + amine DMAEMA (CQ) or bisacylphosphinic oxide (BAPO). A commercial orthodontic resin composite (Transbond XT) was used as control. The materials were then distributed into two groups, according to the photoactivation condition: directly or through a ceramic bracket, for $20 \mathrm{~s}$ at $1200 \mathrm{~mW} / \mathrm{cm} 2$. In the sequence, fifteen composite disks, $5 \mathrm{~mm}$ of diameter and $1 \mathrm{~mm}$ of thickness, were made for each of the eight groups. The degree of conversion (DC) was determined by means of Raman spectroscopy. Knoop hardness (KHN) was measured immediately after confection and after 24 hours of storage in $100 \%$ ethanol for indirect crosslink density (CLD) evaluation. Data were analyzed using two-way ANOVA followed by Tukey's test $(\alpha=0.05)$. Results: The DC of the BAPO composite was significantly higher in comparison to the other materials, regardless of the photoactivation condition. The KHN was significantly different between the composite groups in the following sequence: BAPO> Transbond XT> CQ> PPD. The direct photoactivation presented higher KHN values, regardless the type of material. Regarding the CLD, there was statistical difference only for the material factor, as follow: $\mathrm{PPD}>\mathrm{BAPO}=\mathrm{CQ}=$ Transbond $\mathrm{XT}$. Conclusion: The photoinitiator type and the photoactivation condition had a significant influence on the physical-mechanical properties of the evaluated materials.

Descriptors: Orthodontics; Composite Resins; Dental Photoinitiators; Dental Curing Lights.

\section{Resumo}

Objetivo: o objetivo deste estudo foi avaliar as propriedades físico-mecânicas de resinas ortodônticas experimentais, contendo diferentes sistemas fotoiniciadores e fotoativadas por meio de um braquete cerâmico, utilizando uma unidade de cura por diodo emissor de luz de alta irradiância e amplo espectro. Métodos: Compósitos de resina experimental (50:50 BisGMA / TEGDMA: partículas silanizadas de feldspato $60 \%$ ) foram formulados com diferentes fotoiniciadores de acordo com os seguintes grupos: fenilpropaneamina + amina DMAEMA (PPD), canforoquinona + amina DMAEMA (CQ) ou óxido bisacilfosfínico (BAPO). Um compósito de resina ortodôntica comercial (Transbond XT) foi usado como controle. Os materiais foram então distribuídos em dois grupos, de acordo com a condição de fotoativação: diretamente ou por meio de braquete cerâmico, por $20 \mathrm{~s}$ a $1200 \mathrm{~mW} / \mathrm{cm} 2$. Na sequência, quinze discos de compósitos, de $5 \mathrm{~mm}$ de diâmetro e $1 \mathrm{~mm}$ de espessura, foram confeccionados para cada um dos oito grupos. O grau de conversão (DC) foi determinado por meio de espectroscopia Raman. A dureza Knoop (KHN) foi medida imediatamente após a confecção e após 24 horas de armazenamento em etanol 100\% para avaliação da densidade de reticulação indireta (CLD). Os dados foram analisados por ANOVA de dois fatores seguida do teste de Tukey $(\alpha=0,05)$. Resultados: O DC do compósito BAPO foi significativamente maior em comparação aos outros materiais, independentemente da condição de fotoativação. O KHN foi significativamente diferente entre os grupos de compósitos na seguinte sequência: BAPO> Transbond $X T>C Q>P P D$. A fotoativação direta apresentou maiores valores de KHN, independentemente do tipo de material. Em relação ao CLD, houve diferença estatística apenas para o fator material, conforme segue: $\mathrm{PPD}>\mathrm{BAPO}=\mathrm{CQ}=$ Transbond XT. Conclusão: $\mathrm{O}$ tipo de fotoiniciador e a condição de fotoativação tiveram influência significativa nas propriedades físico-mecânicas dos materiais avaliados.

Descritores: Ortodontia; Resinas Compostas; Fotoiniciadores Dentários; Luzes de Polimerização Odontológica.

\section{Resumen}

Objetivo: El objetivo de este estudio fue evaluar las propiedades físico-mecánicas de resinas de ortodoncia experimentales, que contienen diferentes sistemas fotoiniciadores y fotoactivados a través de un bracket cerámico, utilizando una unidad de curado de diodos emisores de luz de alta irradiancia y amplio espectro. Métodos: Se formularon compuestos de resinas experimentales (50:50 BisGMA / TEGDMA: 60\% de partículas silanizadas de feldespato) con diferentes fotoiniciadores de acuerdo con los siguientes grupos: fenilpropanoamina + amina DMAEMA (PPD), canforquinona + amina DMAEMA (CQ) u óxido bisacilfosfínico (BAPO). Se utilizó como control un composite de resina ortodóncica comercial (Transbond XT). A continuación, los materiales se distribuyeron en dos grupos, según la condición de fotoactivación: directamente o a través de un soporte cerámico, durante $20 \mathrm{~s}$ a $1200 \mathrm{~mW} / \mathrm{cm} 2$. En la secuencia, se hicieron quince discos de compuestos, de $5 \mathrm{~mm}$ de diámetro y $1 \mathrm{~mm}$ de espesor, para cada uno de los ocho grupos. El grado de conversión (DC) se determinó mediante espectroscopía Raman. La dureza Knoop (KHN) se midió inmediatamente después de la confección y después de 24 horas de almacenamiento en etanol al 100\% para la evaluación de la densidad de reticulación indirecta (CLD). Los datos se analizaron usando ANOVA de dos vías seguido de la prueba de Tukey $(\alpha=0.05)$. Resultados: La CD del compuesto BAPO fue significativamente mayor en comparación con los otros materiales, independientemente de la condición de fotoactivación. EI KHN fue significativamente diferente entre los grupos de compuestos en la siguiente secuencia: $\mathrm{BAPO}>$ Transbond $\mathrm{XT}>\mathrm{CQ}>\mathrm{PPD}$. La fotoactivación directa presentó valores de KHN más elevados, independientemente del tipo de material. Con respecto al CLD, hubo diferencia estadística solo para el factor material, como sigue: $P P D>B A P O=C Q=$ Transbond $X T$. Conclusión: El tipo de fotoiniciador y la condición de fotoactivación influyeron significativamente en las propiedades físico-mecánicas de los materiales evaluados.

Descriptores: Ortodoncia; Resinas Compuestas; Fotoiniciadores Dentales; Lámparas de Polimerización Dental.

INTRODUCTION

$$
\text { Currently, photoactivated composite }
$$

resins have been widely used in Orthodontics for bracket bonding ${ }^{1}$. The polymerization initiator 
system of these composites consists of a photosensitive molecule (initiator) and a tertiary amine (co-initiator). The exposure of these components to a light with a suitable wavelength promotes excitation of the photosensitive molecule, which interacts with the amine, forming free radicals that attack the carbon double bonds of the monomers present in the composite, converting them into polymers. The main photosensitive molecule (photoinitiator) used in resinous composites is camphorquinone $(C Q)^{2-4}$, a dark yellow compound which, at high concentrations in the resin formulation, may result in an undesirable yellowing effect ${ }^{2,5}$. In order to optimize the aesthetic effect, different photoinitiators, such as bisacylphosphinic oxide (BAPO) and phenylpropane (PPD) have been tested ${ }^{3,5-7}$.

In the last few years, third generation light emitting diode appliances (LED) have been introduced on the market. Such equipment exhibits an additional light emission peak, which has a lower light intensity in comparison to the main peak ${ }^{5,8}$. Such configuration, combined with a broad light emission spectrum presented by of some models, aims to promote a suitable degree of conversion in a shorter polymerization period, reducing the chair time ${ }^{5,9,10}$. The additional light peak and the intensity control presented by third generation LED curing unit allows it to better activate photoinitiators other than the commonly used $\mathrm{CQ}$, considering the most of these molecules present an absorption peak in the ultraviolet region (close to $390 \mathrm{~nm}$ ) ${ }^{6}$.

The quality of the polymerization promoted by the curing light is directly related to the fundamental properties of the composite resins, such as the degree of conversion ${ }^{8,10,11-14}$, superficial hardness ${ }^{15,16}$ and hardness as an indirect factor for the indirect crosslink density evaluation.

To date, few data is available regarding the photoinitiator systems present in composite resins for orthodontic bonding ${ }^{17}$. Also, there is still lack of evidence regarding the correlation between the physical-mechanical properties of composite resins with different photoinitiators and curing units with suitable wavelength to these respective molecules. Therefore, the aim of this study was to evaluate the degree of conversion (DC), Knoop hardness (KHN) and crosslink density (CLD) of experimental orthodontic resins, containing different photoinitiators systems and photoactivated through a ceramic bracket, using a high irradiance and wide spectrum LED curing unit. The hypotheses of this study were: 1) the different groups of experimental composites resins with present different physical-mechanical properties 2) the interposition of the ceramic bracket will have no effect on the properties of the tested composites.

MATERIAL AND METHOD

- Experimental composite resin formulation

The composites used in this study had a resin composed of a 50:50 mixture of bisphenolA glycerolatedimetacrylate (BisGMA) and triethylene glycol dimethacrylate (TEGDMA) monomers with $0.1 \%$ of the hydroxybutyl toluene inhibitor (BHT). Different photoinitiators were added to the resin, according to the group: $0.5 \mathrm{wt} \%$ bis acylphosphinic oxide (BAPO); $0.5 \mathrm{wt} \%$ phenylpropadione $+1 \mathrm{wt} \%$ dimethylamino ethyl methacrylate (PPD) and $0.5 w t \%$ camphorquinone $+1 w t \%$ dimethylamino ethyl methacrylate (CQ). The composites were produced by combining the resin with $60 \mathrm{wt} \%$ silanated feldspar (1 $\mu \mathrm{m}$ average size, Microspar, HPF The Mineral Engineers, QuarzwerkeGmbH, Frechen) and mixed at $2000 \mathrm{rpm}$ for 40 s in a centrifugal speed mixer (DAC 150, Flacktek, South Carolina). The commercial composite Transbond XT resin (3M Unitek, Monrovia, USA) was used as a control material (C) (45:55 bisphenol $A$ ethoxylated dimethacrylate (BisEMA) / TEGDMA; 0.3wt\% $\mathrm{CQ}$; 0.03wt\% hydroquinone).

- Sample preparation

The composites resins were then distributed into two groups, according to the photoactivation condition: direct contact (control) or through the interposition of polycrystalline orthodontic bracket (Iceram, Orthometric, Marília, SP, Brazil). Composite discs $(n=15)$ of $5 \mathrm{~mm}$ in diameter and $1 \mathrm{~mm}$ in thickness were then made according to the conditions of each of the eight groups, in an environment with controlled temperature at $25^{\circ} \mathrm{C}$. The specimens were prepared by aid of standardized polyvinylsiloxane matrices, filled with the materials in a single increment and pressed between polyester strips and glass sheets. The materials were then cured with a single exposure from the curing light (Valo Ortho, Opal Orthodontics by Ultradent Products, South Jordan, UT, USA), for $20 \mathrm{~s}$ at $1200 \mathrm{~mW} / \mathrm{cm} 2$.

After the photoactivation protocol, the specimens were individually stored for 24 hours in a dry and protected from light environment, at $37^{\circ} \mathrm{C}$, and then submitted to finishing with 600 and 1200 granulation silicon carbide sandpapers (Norton SA, São Paulo, SP, Brazil). In each group, 5 of the specimens were used to evaluate the degree of conversion and 10 to evaluate the hardness and crosslink density. 


\section{- Degree of conversion}

After 24 hours, the specimens were submitted to micro-Raman spectroscopy for the DC analysis ${ }^{18}$. First, the micro-Raman spectrophotometer (Senterra spectrophotometer Bruker, Ettlingen, Baden-Württemberg, Germany) was calibrated using a silica sample and thus verifying the alignment of the laser. After calibration, the materials were measured according to the experimental groups using the following parameters: a magnification of $20 \mathrm{x}$ (Olympus microscope, London, UK), with a Neon laser $(1 \mu \mathrm{m})$ with $532 \mathrm{~nm}$ of length wave and $20 \mathrm{~mW}$ of power, with spatial resolution of 3 $\mu \mathrm{m}$, spectral resolution of $5 \mathrm{~cm} \mathrm{-1}$, in a time of $20 \mathrm{~s}$ with 4 co-additions. Spectra of each of the unpolymerized materials were obtained as reference for calculating the degree of conversion. Then, spectra of each of the specimens were obtained at two randomized sites. The spectra were processed by specific software (Opus Spectroscopy, version 6.5) to calculate the content of carbon monomer double bonds converted to polymer, and the values obtained were obtained in the following formula: $\mathrm{GC}(\%)=(1-[\mathrm{R} /$ polymerized $\mathrm{R})] \times 100$, where "R" corresponds to the product of the division of the aliphatic content $(1639 \mathrm{~cm}-1)$ by the aromatic $(1609 \mathrm{~cm} \mathrm{-1)}$ of the polymerized and unpolymerized material.

\section{- Knoop hardness}

The KHN of the specimens was measured using a microdurometer (HMV 2000, Shimadzu, Tokyo, Japan) with a $50 \mathrm{~g}$ load applied for 5 seconds. Three indentations per specimen were performed on the surface that had direct contact with the light (top) and the $\mathrm{KHN}$ mean was calculated.

\section{- Density of crosslinks}

For the indirect analysis of the crosslink density, after the initial top hardness (HK1) evaluation, the specimens were immersed in ethanol for 24h. After this period, the top hardness was again measured (HK2), using the same parameters. The softening rate of the specimens was calculated by the following formula:

\section{Softening rate $=100-(H K 2 \times 100 / H K 1)$ \\ - Statistical analysis}

Data were check for normality and homogeneity of variances by a Shapiro- Wilk and Levine tests, respectively. In sequence, data were submitted to two-way ANOVA followed by Tukey's test $(\alpha=0.05)$.

RESULTS

\section{- Degree of conversion}

The mean and standard deviation values from the degree of conversion analysis are described in Table 1. The analysis of variance showed significant difference for the both photoinitiator $(p<0.0001)$ and photoactivation condition ( $p<0.0001)$ factors, as well for the interaction photoinitiator * photoactivation condition " $(p=0.0011)$.

Table 1. Mean (\%) and standard deviation values for the DC in the different groups $(n=5)$

\begin{tabular}{c|c|c}
\hline \multirow{2}{*}{ Photoinitiator } & \multicolumn{2}{|c}{ Photoactivation condition } \\
\cline { 2 - 3 } & Direct & Interposed \\
\hline Transbond XT & $40.80( \pm 4.02) \mathrm{cB}$ & $30.16( \pm 4.53) \mathrm{cA}$ \\
\hline PPD & $50.68( \pm 4.81) \mathrm{bA}$ & $48.03( \pm 1.59) \mathrm{bA}$ \\
\hline BAPO & $76.42( \pm 1.62) \mathrm{aA}$ & $71.85( \pm 1.34) \mathrm{aA}$ \\
\hline CQ & $50.47( \pm 7.65) \mathrm{bB}$ & $32.90( \pm 2.86) \mathrm{cA}$ \\
\hline \multirow{2}{*}{ *Mean values followed by different capital letters on the row and lower case in the } \\
column indicate statistically significant difference $(p<0.05)$.
\end{tabular}
column indicate statistically significant difference $(p<0.05)$.

- Knoop hardness

The mean and standard deviation values of $\mathrm{KHN}$ are described in Table 2. The analysis of variance showed significant statistical difference for both photoinitiator ( $p<0.0001)$ and photoactivation condition ( $p<0.0001$ ) factors. There was no significant difference in the interaction between photoinitiator photoactivation condition" ( $p=0.7234)$.

Table 2. Mean (KHN) and standard deviation values for the $\mathrm{KHN}$ in the different groups $(n=10)$

\begin{tabular}{|c|c|c|c|}
\hline \multirow{2}{*}{ Photoinitiator } & \multicolumn{2}{|c|}{ Photoactivation condition } & \multirow{2}{*}{$\begin{array}{c}\text { General } \\
\text { mean/ } \\
\text { Photoinitiator }\end{array}$} \\
\hline & Direct & Interposed & \\
\hline Transbond XT & $44.80( \pm 5.76)$ & $39.33( \pm 6.43)$ & $42.07( \pm 6.57) \mathrm{B}$ \\
\hline PPD & $27.39( \pm 2.57)$ & $23.37( \pm 4.43)$ & $25.38( \pm 4.08) \mathrm{D}$ \\
\hline BAPO & $54.44( \pm 7.13)$ & $52.21( \pm 9.20)$ & $53.32( \pm 8.09) \mathrm{A}$ \\
\hline CQ & $36.49( \pm 4.84)$ & $30.37( \pm 3.37)$ & $33.43( \pm 5.13) \mathrm{C}$ \\
\hline $\begin{array}{l}\text { General mean/ } \\
\text { Photoactivation } \\
\text { condition }\end{array}$ & $40.78( \pm 11.35)$ a & $36.32( \pm 12.46) \mathrm{b}$ & \\
\hline
\end{tabular}

According to the statistical analysis for the photoinitiator variable, $\mathrm{KHN}$ had a significant difference between the groups in the following sequence: $\mathrm{BAPO}>$ Transbond $\mathrm{XT}>\mathrm{CQ}>\mathrm{PPD}$.

Regarding the condition of photoactivation, the direct photoactivation, regardless of the photoinitiator, presented greater hardness when compared to the photoactivation through the polycrystalline bracket.

\section{- Density of crosslinks}

Mean and standard deviation values of the CLD are described in Table 3. The analysis of variance showed statistical difference only for the photoinitiator factor $(p=0.045)$, showing no significant difference for the photoactivation condition ( $p=0.2573$ ) or for the interaction between photoinitiator * photoactivation condition" factors $(p=0.312)$.

Table 3. Mean (\%) and standard deviation values for the CLD in the different groups $(n=10)$

\begin{tabular}{l|c|c|c}
\hline \multirow{2}{*}{ Photoiniator } & \multicolumn{2}{|c|}{ Photoactivation condition } & $\begin{array}{c}\text { General mean } \\
\text { Photoinitiator }\end{array}$ \\
\cline { 2 - 4 } & Direct & Interposed & \\
\hline Transbond XT & $43.77( \pm 7.60)$ & $36.26( \pm 14.47)$ & $40.02( \pm 11.89) \mathrm{B}$ \\
\hline PPD & $51.38( \pm 6.57)$ & $47.00( \pm 6.39)$ & $49.18( \pm 6.70) \mathrm{A}$ \\
\hline BAPO & $40.80( \pm 10.09)$ & $45.39( \pm 12.77)$ & $43.10( \pm 11.45) \mathrm{AB}$ \\
\hline CQ & $40.55( \pm 9.20)$ & $43.94( \pm 13.20)$ & $42.24( \pm 11.25) \mathrm{AB}$ \\
\hline $\begin{array}{l}\text { General mean } / \\
\text { Photoactivation } \\
\text { condition }\end{array}$ & $44.97( \pm 10.15) \mathrm{a}$ & $42.30( \pm 11.54) \mathrm{a}$ & \\
$\begin{array}{l}{ }^{*} \text { Mean values followed by different capital letters in the column and lower case in the row } \\
\text { indicate statistically significant difference }(p<0.05) .\end{array}$
\end{tabular}


Statistical analysis showed that, regardless of the photoactivation condition, there was a significant difference between the photoinitiator groups, in the following sequence: $\mathrm{PPD}>\mathrm{BAPO}=\mathrm{CQ}=$ Transbond XT. Regarding the condition of photoactivation, there was no difference between the groups.

DISCUSSION

The aim of this study was to evaluate the physical-mechanical properties of experimental orthodontic composites, containing different photoinitiators systems and photoactivated through a ceramic bracket, using a high irradiance and wide spectrum light emitting diode curing unit.

It is known that although the energy dose (defined as the irradiance $x$ time) is an important factor, the interaction between the absorption spectrum of the photoinitiator and the emission spectrum of the photoactivator unit plays a fundamental role in the curing process ${ }^{19-23}$. Due to differences in the light absorption spectra of the alternative photoinitiators evaluated in this study, a wide light spectrum source was used for the photoactivation of the specimens, capable of covering the different absorption peaks ${ }^{3,5,6}$.

According to the results of this study, it could be observed that the degree of conversion was significantly different between the photoinitiators, regardless of the photoactivation condition, partially accepting the first hypothesis. Camphorquinone is a photosensitive molecule widely used in the composition of composites, having proven efficiency in initiating the monomers conversion process ${ }^{3}$. In our study, the BAPO composite presented the higher DC in comparison with the $\mathrm{CQ}$ and Transbond $\mathrm{XT}$ groups, both containing camphorquinone in the resin matrix composition. Favarão et al. $^{7}$ also demonstrated in their study a BAPO DC higher than the CQ DC.

The distinct behavior between these initiators can be explained by the differences in their chemical structure and dynamic during the polymerization process. The initiation mechanism of $\mathrm{CQ}$ generates only one free radical derived from the tertiary amine (dimethylamino ethyl methacrylate-DMAEMA) ${ }^{24}$. On the other hand, the cleavage of the molecule BAPO when exposed to the appropriate wavelength generates four free radicals, of which two are potentially active to initiate the polymerization ${ }^{24,25}$.

The PPD composite also presented lower DC in comparison to BAPO. Some studies have shown that the PPD molecule is more efficient when it forms free radicals by photocleavage, which is independent of the addition of a co-initiator ${ }^{3,24,26}$. When a co-initiator is added, such as the DMAEMA, the decomposition of the initiator molecule decreases, reducing its molar extinction coefficient and diminishing the polymerization potential $^{27}$. In the other hand, the DC od PPD was higher than the control and $C Q$ groups, probable due to the fact that it has a higher decomposition rate in comparison to the champhorquinone, favoring the production of free radicals ${ }^{27}$.

A better performance of the BAPO group was also observed through the mechanical properties analysis, showing results consistent to those found in similar studies ${ }^{16,28}$. The results can be justified by their polymerization reaction independent of the presence of a co-initiator (amine), allowing a fast photolysis of its molecule for free radical generation and greater molar extinction coefficient in relation to PPD and $\mathrm{CQ}$. These advantages allowed a more effective polymerization reaction of this composite $^{3,15,26,29}$, hence improving its mechanical performance.

Differently from findings from similar studies $^{5,6,30,31}$, that showed a desirable performance of the PPD molecule, in this study the PPD composite showed the lowest hardness values. This difference can be attributed to the fact that in those studies the PPD acted as coinitiator in resins that also contained $C Q$ in its composition, whereas in the present study, the resin containing PPD had only the amine DMAEMA, without the addition of CQ. On the other hand, Brandt et al. ${ }^{15}$ obtained results similar to those of this study when comparing commercial resins with experimental resins containing camphorquinone, camphorquinone + PPD or only PPD. The resin containing PPD obtained the lowest hardness value, a result that can be attributed to the polymerization kinetics of PPD, which presents a very slow initial polymerization reaction in the viscous compound $^{21}$. During their activation and production of free radicals, due to the high viscosity of the mixture, many molecules re-bind, and thus lose the function of initiators of the polymerization reaction. This fact associated to the short activation time may have impaired the polymerization reaction of the PPD-containing composite and influenced in its poor behavior during the hardness test ${ }^{6,15,21,32}$.

Regarding the crosslinking density, it was observed statistical difference only regarding the photoinitiator type, being that the photoactivation condition did not influenced the results obtained. The PPD composite presented higher softening rate in comparison to the other composited 
tested, which did not have significant difference in between them. The poor behavior presented by the PPD composite can be explained by the slower polymerization reaction of the PPD molecule in comparison to the other photoinitiators, which can produce a more linear polymer with consequently lower crosslink density ${ }^{30}$. The crosslink density can directly interfere on the softening rate of the composite, considering that materials with these conditions would be more suitable to water sorption and, consequently, to hydrolysis of the resin matrix.

It was observed in this study, that the photoactivation condition, regarding the interposition or not of the ceramic bracket, negatively affected the degree of conversion and the Knoop hardness of the composites tested, rejecting the second hypothesis. This result is in line with the study by Delgado et al. ${ }^{3}$, in which the author showed that the thickness of the ceramic veneers reduced their radiance of the multiwave LED in all wavelengthspectra. The use of the ceramic bracket sought to simulate the clinical procedure of cementation, where the orthodontic composite is polymerized thorough the interposition of a bracket. Although the ceramic appliance allows a better light passing in comparison with metal and plastic bracket ${ }^{33}$, the interposition of this device still promotes loss of irradiance due to the absorption and scattering of the light coming from the photoactivator, influencing the amount of light received by the composite resin beneath it, and, consequently, on its physical-mechanical properties.

CONCLUSION

Considering the results obtained in the present study, it can be concluded that the photoinitiator type and the photoactivation condition had a significant influence on the physical-mechanical properties of the evaluated materials. The BAPO photoinitiator obtained the best performance in the evaluated properties, independent of the photoactivation condition, which could indicate it as a promising alternative for the replacement of the conventional initiator system (CQ / amine).

\section{REFERENCES}

1. Hedayati Z, Farjood A. Evaluation of microleakage under orthodontic brackets bonded with nanocomposites. Contemp Clin Dent. 2018;9(3):361-6.

2. Alvim $\mathrm{HH}$, Alecio AC, Vasconcellos WA, Furlan $M$, de Oliveira JE, Saad JR. Analysis of camphorquinone in composite resins as a function of shade. Dental Materials. 2007;23(10):1245-9.
3. Delgado AJ, Castellanos EM, Sinhoreti M, Oliveira DC, Abdulhameed N, Geraldeli S, Sulaiman TA, Roulet JF. The use of different photoinitiator systems in photopolymerizing resin cements through ceramic veneers. Oper Dent. 2019;44(4):396-404.

4. Pratap B, Gupta RK, Shekhawat DS, Yadav A, Chaabra D, Nag M. Physical and mechanical characterization of nanoalumina filled resin based dental composites. Materials Today. 2020;28(4):2171-3.

5. Sim JS, Seol HJ, Park JK, Garcia-Godoy F, Kim $\mathrm{HI}$, Kwon YH. Interaction of LED light with coinitiator-containing composite resins: effects of dual-peaks. J Dent. 2012;40(10):836-42.

6. Lee DS, Jeong TS, Kim S, Hyung-II Kim HI, Kwon YH. Effect of dual-peak LED unit on the polymerization of coinitiator-containing composite resins. Dent Mater J. 2012;31(4):656-61.

7. Favarão J, Oliveira DCRS, Zanini MM, Rocha MG, Correr-Sobrinho L, Sinhoreti MAC. Effect of curing-light attenuation on color stability and physical and chemical properties of resin cements containing different photoinitiators. J. Mech. Behav. Biomed. Mater. 2021;113.

8. Çörekçi B, Malkoç S, Öztürk B, Gündüz B, Toy $\mathrm{E}$. Polymerization capacity of orthodontic composites analyzed by Fourier transform infrared spectroscopy. Am J Orthod Dentofacial Orthop. 2011;139(4):299-304.

9. Çörekçi B, Irgin C, Halicioglu K, Dursun S, Yavuz MZ. Effects of plasma-emulating lightemitting diode (LED) versus conventional LED on cytotoxic effects and polymerization capacity of orthodontic composites. Hum Exp Toxicol. 2014;33(10):1000-7.

10. Amato PAF, Martins RP, Cruz, CAS, Capella MV, Martins LP. Time reduction of light curing: Influence on conversion degree and microhardness of orthodontic composites. Am J Orthod Dentofacial Orthop. 2014;146(1):40-5.

11. Sostena MDS, Nogueira RA, Grandini CR, Moraes JCS. Glass transition and degree of conversion of light cured orthodontic composite. J Appl Oral Sci. 2009;17(6):570-3.

12. Uzunova Y, Lukanov L, Tsanova PV, Filipov I. Spectroscopic, chromatographic and morphological study of photopolymerized dental composites. Digest Journal of Nanomaterials and Biostructures. 2012;7(4):1825-32.

13. Giorgi MCC, Lima DANL, Marchi GM, Ambrosano GM, Aguiar FHB. Influence of softening test and light-activation protocols on resin composite polymer structure. Eur Journal Dent. 2014;8(1):9-14.

14. Purushothaman $D$, Kailasam $V$, Chitharanjan $A B$. Bisphenol A release from orthodontic adhesives and its correlation with the degree of conversion. Am Journal Orthod Dentofacial Orthop. 2015;147(1):29-36. 
15. Brandt WC, Schneider LFJ, Frollini E, CorrerSobrinho L, Sinhoreti MAC. Effect of different photo-initiators and light curing units on degree of conversion of composites. Braz Oral Res. 2010;24(3):263-70.

16. Salgado VE, Albuquerque PP, Cavalcante LM, Pfeifer CS, Moraes RR, Schneider LF. Influence of photoinitiator system and nanofiller size on the optical properties and cure efficiency of model composites. Dent Mater. 2014;30(10):e264-71.

17. Santini A, McGuinness N, Nor NA. Degree of conversion of resin-based orthodontic bonding materials cured with single-wave or dual-wave LED light-curing units. J Orthod. 2014; 41(4): 292-8.

18. Hass V, Luque-Martinez I, Sabino NB, Loguercio AD, Reis A. Prolonged exposure times of one-step self-etch adhesives on adhesive properties and durability of dentine bonds. J Dent. 2012;40(12):1090-102.

19. Ogunyinka A, Palin WM, Shortall AC, Marquis PM. Photoinitiation chemistry affects light transmission and degree of conversion of curing experimental dental resin composites. Dent Mater. 2007;23(7):807-13.

20.Schneider LF, Cavalcante LM, Consani S, Ferracane JL. Effect of co-initiator ratio on the polymer properties of experimental resin composites formulated with camphorquinone and phenyl-propanedione. Dent Mater. 2009;25(3):369-75.

21. Brandt WC, Tomaselli LO, Correr-Sobrinho L, Sinhoreti MAC. Can phenyl-propanedione influence Knoop hardness, rate of polymerization and bond strength of resin composite restorations? J Dent. 2011;39(6): 438-47.

22. Flury S, Lussi A, Hickel R, Ilie N. Light curing through glass ceramics with a second-and a third-generation LED curing unit: effect of curing mode on the degree of conversion of dualcuring resin cements. Clin Oral Invest. 2013; 17:2127-37.

23. Manojlovic D, Dramićanin MD, Lezaja M, Pongprueksa $\mathrm{P}$, Van Meerbeek B, Miletic V. Effect of resin and photoinitiator on color, translucency and color stability of conventional and low-shrinkage model composites. Dent Mater. 2016;32(2):183-91.

24. de Oliveira DC, Rocha MG, Gatti A, Correr AB, Ferracane JL, Sinhoreti MAC. Effect of different photoinitiators and reducing agents on cure efficiency and color stability of resin-based composites using different LED wavelengths. J Dent. 2015;43(12):1565-72.

25. Salgado VE, Borba MM, Cavalcante LM, Moraes RR, Schneider LF. Effect of photoinitiator combinations on hardness, depth of cure, and color of model resin composites. J Esthet Restor Dent. 2015;27(S1):S41-8.
26. Neumann MG, Miranda WG, Schmitt CC, Rueggeberg FA, Corrêa IC. Molar extinction coefficients and the photon absorption efficiency of dental photoinitiators and light curing units. J Dent. 2005;33:525-32.

27. Sun JG, Chae KH. Properties of 2-3butanedione and 1-phenyl-1,2-propanedione as new photosensitizers for visible light cured dental resin composites. Polymer. 2000; 41:6205-12.

28. Lima CDR, da Silva DB, Vitti RP, Miranda ME, Brandt WC. Mechanical properties of experimental resin cements containing different photoinitiators and co-initiators. Clin Cosmet Investig Dent. 2019;11:285-90.

29. Ikemura K, Endo T. A review of the development of radical photopolymerization initiators used for designing light-curing dental adhesives and resin composites. Dent Mater J. 2010;29(5):481-501.

30. Oliveira DCRS, Souza-Junior EJ, Dobson A, Correr ARC, Brandt WC, Sinhoreti MAC. Evaluation of phenyl-propanedione on yellowing and chemical-mechanical properties of experimental dental resin-based materials. J Appl Oral Sci. 2016;24(6):555-60.

31. Segreto DR, Naufel FS, Brandt WC, Guiraldo RD, Correr-Sobrinho L, Sinhoreti MA. Influence of photoinitiator and light-curing source on bond strength of experimental resin cements to dentin. Braz Dent J. 2016;27(1):83-9.

32. Schneider LF, Pfeifer CS, Consani S, Prahl SA, Ferracane JL. Influence of photoinitiator type on the rate of polymerization, degree of conversion, hardness and yellowing of dental resin composites. Dent Mater. 2008;24(9): 1169-77.

33. Bolaños-Carmona $V$, Zein $B$, Menendéz-Núñez $M$, Sánchez-Sánchez $P$, Ceballos-García $L$, Gonzáles-Lopez S. Influence of the bracket on bonding and physical behavior of orthodontic resin cements. Dent Mater J. 2015;34(4): 449-57. 


\section{CONFLICTS OF INTERESTS}

The authors declare no conflicts of interests.

\section{CORRESPONDING AUTHOR}

\section{Gisele Maria Correr}

School of Health Sciences,

Graduate Program in Dentistry

Universidade Positivo

Pedro Viriato Parigot de Souza st., 5300

81280-330 Curitiba - PR, Brazil

Phone: 5541 3526-5125.

E-mail: gisele.nolasco@up.edu.br 